\title{
Less or More Intensive Crop Arable Systems of Alentejo Region of Portugal: what is the sustainable option? ${ }^{1}$
}

\author{
Carlos Marques², Fátima Baptista ${ }^{3}$, Luis Leopoldo Silva ${ }^{4}$, \\ Dina Murcho ${ }^{5}$ and Maurícia Rosado 6
}

\begin{abstract}
Competitiveness of traditional arable crop system of Alentejo region of Portugal has been questioned for long. Discussion and research on the sustainability of the system has evolved on two contrasted alternative options for production technologies to traditional system. On the one hand reduced and no tillage systems aim to more extensive technical operations reducing costs and maintaining production, or even to increase it in the long run as soil fertility improves. On the other hand, input intensification using irrigation, as a complement in the last stage of crop cycle or always when needed, aimed to increase system production levels. To evaluate competitiveness and sustainability of arable crop system we evaluated traditional rotation technology and alternative no tillage and irrigation systems and analyze their farm economic results as well as their energy efficiency and environmental impacts. The analysis of the impact of no tillage and irrigation on arable land production system showed that both alternatives contributed to cost savings and profit earnings, energy savings and reduced GHG emissions, increasing physical and economic factor efficiency. Research and technological development of both options are worthwhile to promote competitiveness and sustainability of arable crop production systems of the Alentejo region in Portugal.
\end{abstract}

Key-words: Alentejo, arable crop system, economic and environmental analysis, trade-offs, energy efficiency.

JEL Classification: Q10, Q51.

DOI: http://dx.doi.org/10.1590/1234-56781806-94790053s01006

1. The authors acknowledge the contributions of José Rafael Silva and José Peça of Portuguese team and others elements of countries teams of AGREE project (FP7-KBBE-2011-5-289139).

2. Professor catedrático, University of Évora, Department of Management, CEFAGE, Apartado 94, 7002-554 Évora, Portugal. E-mail: cmarques@uevora.pt

3. Professora auxiliar, University of Évora, Department of Rural Engineering, ICAAM, Apartado 94, 7002-554 Évora, Portugal. E-mail: fb@uevora.pt

4. Professor auxiliar, University of Évora, Department of Rural Engineering, ICAAM, Apartado 94, 7002-554 Évora, Portugal. E-mail: 1lsilva@uevora.pt

5. Research assistant for AGREE project, University of Évora, Department of Rural Engineering. E-mail: dinam@uevora.pt

6. Professora auxiliar, University of Évora, Department of Animal Science, ICAAM, Apartado 94, 7002-554 Évora, Portugal. E-mail: mmcr@uevora.pt 


\section{Introduction}

Production of cereals, namely wheat for production of bread to provide a basic food for population, the base cereal of the traditional arable crop system of dryland in Alentejo, has been for long encouraged and supported by Portuguese agricultural and food policies. Since the wheat campaigns of Salazar, in the early decades of the past century until the preparation adjustments and procedures of Portuguese entrance to the European Economic Community (EEC), a couple years before the formal date of 1986 due to need to adopt the Common Agriculture Policy (CAP), a set of domestic policies were in place to guarantee high producer prices and maintain consumer prices low. As a result Portuguese market prices for producers and consumers were above and below international levels, respectively.

Competitiveness of traditional arable crop systems of Alentejo has been long questioned (MARQUES, 1988). In more recent times, discussion and research has evolved on two contrasted alternative evolution options for production technologies. On the one hand reduced and no tillage systems aim to more extensive technical operations reducing costs and maintaining production (or even to increase it in the long run as soil fertility gets better). On the other hand, input intensification using irrigation, as a complement in the last stage of crop cycle or always when needed, aimed to increase system production levels.
The context of an European project on AGRiculture and Energy Efficiency (http://www. agree.aua.gr) involving case studies that were analyzed to understand potential changes and drawbacks associated with energy efficiency measures for agricultural production systems of several European countries, including Portugal, that included a work package on interactions and trade-offs of energy used in agricultural production systems with environmental impacts and farm economic results, provided the right opportunity to raise and evaluate the issue of these options on the competitiveness and sustainability of Alentejo arable crop system. Hence, one of the Portuguese case studies that were set is the arable crop system of Alentejo. In the context of AGREE alternatives constitute energy efficiency measures. In this paper and in general terms these measures constitute alternative technologies.

The objective is to evaluate competitiveness and sustainability of less and more intensive crop arable systems in the Alentejo. These two options are represented by considering the two alternative technological evolutions of no tillage and of irrigation to traditional technology. This paper reports their evaluation based on energy efficiency parameters of traditional dryland wheat production rotation technology and alternative no tillage and irrigation systems and analysis of their farm economic results as well as environmental impacts. Results will evaluate potential gains and trade-offs and provide 
orientation for future research and development of this system.

In addition to this introduction, this paper includes four parts. In the following section a brief characterization of the farm setting and technology alternatives considered that characterize the case. The third part lays out the major aspects of the methodology used. Results are presented and discussed in the next part. The paper ends with major conclusions and their policy implications.

\section{The case study and the scenarios}

Alentejo is the largest agricultural region of Portugal, with a Mediterranean climate characterized by mild winters and dry and hot summers. Rainfall is between 400 to $600 \mathrm{~mm}$, concentrated in autumn and winter. Average temperature is between 21 and $25{ }^{\circ} \mathrm{C}$, but maximum temperature can be higher than $40^{\circ} \mathrm{C}$ in the summer while minimum is frequently below zero during winter nights. The main limitations imposed by climate on Alentejo's agricultural activities are due to the very dry summer. Only winter-spring crops can be produced. Springsummer crops cannot be produced except in deep soils that preserve some moisture or where irrigation is available (MARQUES, 1988).

Alentejo has more than half of Portuguese agricultural usable area, around 2 out of 3.7 miillion hectares (INE), and the most extensive area of arable land in Portugal. Therefore, arable crop systems of dryland agriculture that sustain land use in agricultural use are very relevant in territorial, economic and environmental terms.

Evaluation of traditional crop farming system of dryland agriculture in the Alentejo is based on a typical farm of 250 hectares, with clay soils (Bvc $+\mathrm{Cb}$ representing $85 \%$ ) in the Beja district (ROSADO, 2009).

\subsection{Conventional technology}

The farm production system is based on a four years crop rotation (sunflower - durum wheat
1 - green peas - durum wheat 2) established to achieve high production levels of cereals. Usually, cereal, namely durum wheat, because of specific subsidy policies, or other cash cereal crop, alternates with sunflower and peas. Sunflower is used to profit from soil preparation in the winter of the year before wheat growing and green peas are included to restore soil fertility and avoid consecutive years of wheat. Traditional technology is based on soil preparation with deep ploughing followed by two chisel passages during winter, and one before sunflower sowing, early in the spring. Sowing density of sunflower is $4 \mathrm{~kg} / \mathrm{ha}$ of seeds (75000 plants). Sunflower is harvested in August with a productivity of $850 \mathrm{~kg} / \mathrm{ha}$. Durum wheat installation is then prepared with chisel and disc harrowing followed by sowing (200 kg seeds/ha) and fertilization (300 kg/ha of N20: P20: K0). Usually a crop weed control operation takes place $(0.02 \mathrm{~kg} / \mathrm{ha}$ of Tribenuron-Methyl and $0.5 \mathrm{~L} /$ ha of Clodinafop + Cloquintocete) followed by a fertilization with $150 \mathrm{~kg} / \mathrm{ha}$ (N 27\%). Harvest is in July, with average yield of 3 ton/ha of grain and 1.5 ton/ha of straw. Green peas sowing occurs in January, with $150 \mathrm{~kg} / \mathrm{ha}$, after harrowing and two chisel passages for soil preparation. As for sunflower, green peas require neither herbicides nor fertilization treatments. Harvest is also in July, with productivities of $1100 \mathrm{~kg} / \mathrm{ha}$.

To perform the above described field operations the farm machinery consists in one 105 HP tractor, one 9 tons trailer, one disc harrow, one chisel, one drill with 25 lines, a fertiliser distributor, a straw baler, a rake and a precision seeder. All the machines and agricultural equipment's are stored in a $75 \mathrm{~m}^{2}$ building. The farmer also rents an $85 \mathrm{HP}$ tractor with a plow implement, a $1000 \mathrm{~L}$ sprayer, and a combine harvester.

\subsection{No tillage technology}

Reduced tillage has been identified as an efficient measure to reduce input use in agricultural systems. Agricultural systems with reduced tillage need less fuel associated with lower greenhouse gas emissions and lower 
costs for the farmer. Furthermore, a carbon sequestration effect in the soil may further mitigate the net greenhouse gas emissions from agriculture. However, with respect to soil and climate conditions, reduced tillage may also impact crop yields, which counteracts the positive effects.

This technological alternative in Alentejo has been, for long, focus of continuous research and evaluation in technological and economic terms (AZEVEDO and CARY, 1972; CARVALHO et al., 2013, BASCH, 1989, 1991; MARQUES ET BASCH, 2002; MARTINS, 1994, 1996, 2003, 2007; MARTINS and MARQUES, 1995, 2006; ROSADO, 2009). No tillage or direct seeding is being applied in wheat for several years in Portugal, by a small number of farmers, but it's a practice that has been increasing over the years as a sustainable and environmental friendly agricultural practice for wheat production.

No tillage was considered as an alternative technology farming system for all crops. Instead of conventional soil preparation, in late February an herbicide (glyphosate) is applied to prepare the sunflower sowing during March, with a seeder direct drilling. In the following year, normally in the third week of October, a weed control operation is performed using glyphosate (3 L/ha). Wheat sowing is in November, using a seeder direct drilling, with seed density of 200 $\mathrm{kg} / \mathrm{ha}$ and fertilization level of $250 \mathrm{~kg} / \mathrm{ha}$ (N 15: P 15: K 15). In late January there is a fertilization with $140 \mathrm{~kg} / \mathrm{ha}(27 \% \mathrm{~N})$. During February it takes place a crop weeding operation $(0.02 \mathrm{~kg} / \mathrm{ha}$ of Tribenuron-Methyl and $0.5 \mathrm{~L} / \mathrm{ha}$ of Clodinafop + Cloquintocete). The wheat is harvest in July. The average productivities are the same of the traditional farming system, for all crops.

To use no tillage technology the farmer besides renting a $1000 \mathrm{~L}$ sprayer and a combine harvester needs to rent a seeder direct drilling.

\subsection{Irrigation}

In Mediterranean conditions, wheat is a traditional rainfed crop, because generally there is sufficient available water for wheat production. However, and especially in dry years wheat can benefit from supplemental irrigation applied in spring. Irrigation will contribute to increase directly the input use of water and energy required for pumping the water. However, improved energy efficiency can be achieved with higher productivity resulting in higher yields with small increase in energy use. The use of irrigation for wheat production can lead to a great increase in productivity.

Irrigation of wheat in the Alentejo became in economic terms particularly interesting with PAC adjustments in the mid-nineties, the beginning of decoupling process, when payments per hectare replaced institutional prices and a specific class for irrigated land was set. Investments for holes and ponds and irrigation equipments were also publically heavily supported by the orientation policy. The objective of many of the projects that were implemented was to complement conventional technology to apply water in the last part of the crop cycle to increase yields or before if climacteric conditions imposed hydric stress avoiding negative impacts on production levels, and of course be eligible and receive the compensation subsidy which also contributed to the financial and economic feasibility of the project.

However, an additional factor of the irrigation is also important for mixed systems of crops and livestock. Since during summer there is scarcity of field pasture and feed, there is need to produce conserved feed for livestock, namely hay and straw, and to complement feeding with purchased concentrated. The availability of water can be used to increase production and consequently availability of conserved feeds but also be used on irrigated pastures that can substitute for the concentrate and fulfil the feeding requirements of livestock during the summer. These aspects and risk for livestock producers have also been studied for farms in the Alentejo (ANSELMO, 1990; NETO, 1992; MARREIROS, 1992; CARVALHO, 1994).

Not only wheat, but also sunflower and green peas can benefit from irrigation. Most sprinkler 
irrigation systems can be used with these crops, but as the crop area increases moving sprinkler systems present more economic and technical advantages compared to fixed sprinkler irrigation systems.

Soil preparation, sowing and fertilization operations are the same described in the basic scenario but fertilizer levels are increased. The number of irrigations and the amount of applied irrigation water can vary based on the rainfall occurred in each year, with an annual average value of $1200 \mathrm{~m}^{3} /$ ha for all crops of the rotation.

To irrigate investments for water availability and irrigation equipments are necessary and expertise and technological adjustments are required with the increase in some inputs namely water, fertilizers and electricity.

\section{Methodological framework for the analysis of alternative technologies and their impact on energy use, economics and the environment}

The analysis of the environmental and economic trade-offs includes the analysis of energy efficiency measures on the use of direct and indirect energy, greenhouse gas emissions and farm economics. The energy use, environmental and economic analysis are based on a cradle to farm gate analysis, taking all costs and emissions into account needed to produce the agricultural products. The economic cost calculations were based on the economic settings in the considered countries, while for the energy use and greenhouse gas estimates, whenever possible, common methodologies were used.

In order to model potential trade-offs between energy savings, GHG-emissions and farm economics it was necessary to model the relevant energy efficiency measures in simple spreadsheet based models.

The calculations of the energy savings and GHG emissions with the energy efficiency measures were based on the report "State of the Art on Energy Efficiency in Agriculture"
(AGREE ${ }^{7}$ and GOŁASZEWSKI et al., 2012) and extended with regard to GHG emissions. Data on assumptions were, if not stated otherwise, drawn from published data from the Biograce ${ }^{8}$ database.

Estimates for cost savings associated with the energy efficiency measure are based on the use of resources calculated with the farm models. Fixed costs were allocated according to the useful life of the used implements for owned machinery and storage. Prices for outputs, inputs and machinery rented were taken from regional specific data.

EU subsidies considered include the RPU ("Single Payment Scheme"), with the national average value attributed for the year of the study of 174 euros/ha and an additional aid ("PRODER", Programme for Rural Development) for the no tillage alternative of 174 euros/ha (Portaria n. 229-B/2008, March 6). Methodology and results development and analysis for different systems and countries are based on the report "Economic and Environmental Analysis of Energy Efficiency Measures in Agriculture" (Agree Website ${ }^{9}$, MeyerAurich et al., 2013) which includes the Portuguese team contribution.

\section{Relative contribution of different factors on farm energy, CHG emissions and costs and impact of different technologies on energy use, economics and the environment}

Figure 1 shows the relative contribution of the different inputs in total energy consumption, GHG emissions $\left(\mathrm{CO}_{2} \mathrm{eq}\right)$ and farm costs for the crops considered in the conventional production system of this farm, assumed as the base scenario.

Diesel and lubricants followed by fertilizers are responsible for more than 50 and $40 \%$, respectively, of total energy consumed in the production system. The relative importance of these factors is reversed in terms of environmental

\footnotetext{
7. www.agree.aua.gr

8. www.biograce.net

9. www.agree.aua.gr
} 
Figure 1. Relative contribution of different factors used on farm energy, greenhouse gas emissions (GHG) and costs under conventional technology

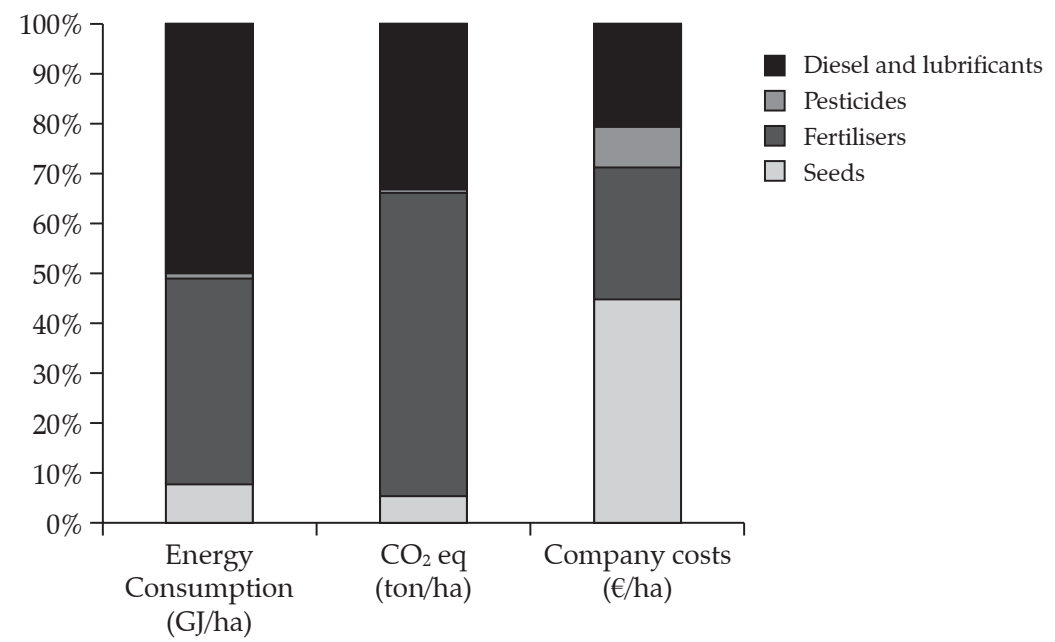

Source: AGREE spreadsheet results for arable crop system of Alentejo.

impacts evaluates in CHG emissions which are particularly high for fertilizers with almost $60 \%$ of total and more than $30 \%$ for diesel and lubricants. Seeds are particularly important for farm costs. The relative high contribution of seeds for the total costs is explained by the fact that two of the crops do not require fertilization and pesticides. Fertilizers and diesel and lubricants represent 25 and $20 \%$ of costs, respectively. Hence, factors have different relative contributions to primary energy consumption, CHG emissions and costs. Small changes in factor use might have high impacts on energy use and GHG emissions but induce relatively lower changes in costs.

This is clear in Table 1 that presents costs, energy consumption and GHG emissions per hectare for conventional and alternative systems described before. Option 1 (no tillage) decreases energy consumption by $42.7 \%$, GHG emissions by $19.5 \%$ and costs by only 8.6. The opposite occurs with option 2 (irrigation). In fact, primary energy consumption increases $94.9 \%$, CHG emissions by $68 \%$ and production costs increase $54.2 \%$. The decrease in the first option is explained by less use of machinery/diesel and fertilisers and the increase in the last one is due to the increase inputs of fertilisers and electricity for irrigation.

Figure 2 represents these effects and also includes farm profit for different options, applied only for the wheat crop. It is possible to see that the two options allow an increase of farm profit (43\% with no tillage mainly due to an agroenvironmental subsidy in place given specially for this type of production technology and more than double with the irrigation option). In the first the increase is due to a decrease of the production costs and an increase in subsidies

Table 1. Annual costs, PEC and GHG emission for different technologies in the farm rotation

\begin{tabular}{lcccccc}
\hline & \multicolumn{2}{c}{ Annual Costs } & \multicolumn{2}{c}{ PEC } & \multicolumn{2}{c}{ GHG } \\
\cline { 2 - 7 } & $\epsilon / h a$ & $\%$ & $M J / h a$ & $\%$ & $\mathrm{CO}_{2} e / h a$ & $\%$ \\
\hline Conventional & 528.43 & 100.0 & 7171.26 & 100.0 & 535.97 & 100.0 \\
No Tillage & 482.90 & 91.4 & 4109.36 & 57.3 & 431.70 & 80.5 \\
Irrigation & 770.25 & 145.8 & 13979.11 & 194.9 & 900.23 & 168.0 \\
\hline
\end{tabular}

Source: AGREE spreadsheet results for arable crop system of Alentejo. 
Figure 2. Impact of different technologies on costs, profit, energy use and greenhouse gas emissions (GHG) per ha of wheat

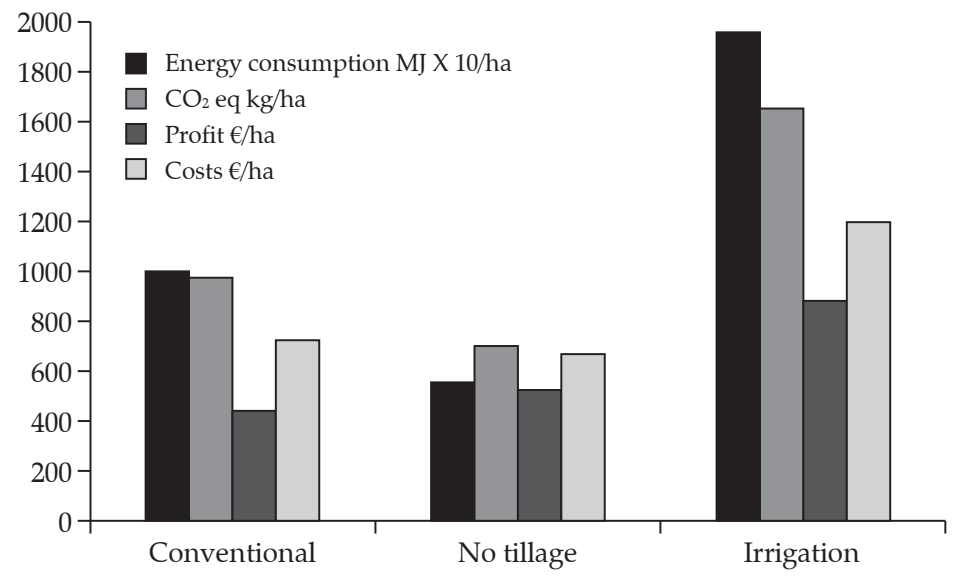

Source: AGREE spreadsheet results for arable crop system of Alentejo.

and in the second due to the increase of yield and receipts that more than compensates cost increase.

Figure 3 presents impact on energy consumption, greenhouse gas emissions (GHG), profits and costs per ton of wheat produced. Results per ton are very different from those presented on a hectare base. In fact, when considering the productions obtained both options result in higher resource efficiency. No tillage and irrigation are win win situations in terms of energy, environmental and economic efficiency. Less energy is consumed, less GHG are emitted and higher farm profit and lower costs are obtained due to reduction of the production costs or either due to the increase of the receipts due to higher productivity in the irrigated option or specific subsidy levels in the no tillage system.

Costs experience a small decrease with a variation per ton of wheat produced of around $8 \%$ with no tillage and $7 \%$ with irrigation and profits per ton for these options, with a $24 \%$ for

Figure 3. Impact of different technologies on costs, profits, energy use and greenhouse gas emissions (GHG) per ton of wheat

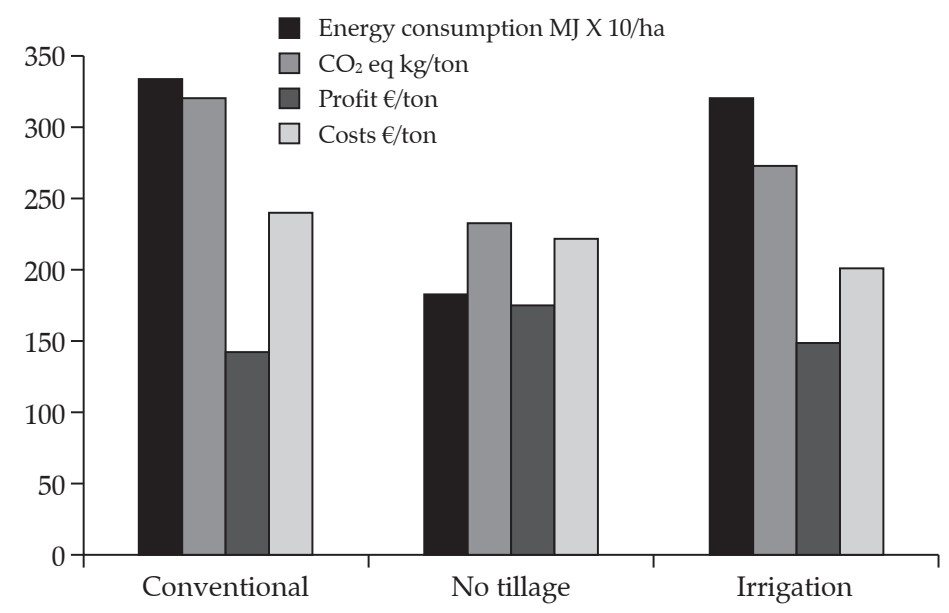

Source: AGREE spreadsheet results for arable crop system of Alentejo. 
no tillage and $4 \%$ for irrigation per ton produced. The no tillage option proves to be particularly relevant as an energy efficiency measure with a reduction of energy consumed by $45 \%$ per ton of wheat produced. The irrigation option also improves energy efficiency with a $3 \%$ reduction. For the $\mathrm{CO}_{2}$ eq a reduction of $30 \%$ and $15 \%$ was attained with these alternative technologies.

Figure 4 shows the differences between the conventional system and the analysed options, on energy, GHG emissions, costs and farm profit per ton of attained wheat yield. It is possible to see that the introduction of irrigation can contribute to the highest savings in the production costs. No tillage allows the higher savings in energy consumption and GHG emissions and the highest increase in farm profit.

\section{Conclusion}

Different inputs contribute in different percentages to total costs, primary energy consumption (PEC) and greenhouse gas emissions (GHG). Diesel and fertilizers represent more than $90 \%$ of energy consumption and emissions but around $45 \%$ of costs. Hence, changes in diesel and fertilizers mix used will have little cost changes but large impacts on energy use and greenhouse gas emissions.

The analysis of the impact of no tillage and irrigation on arable land production system showed that both alternatives contributed to energy savings and reduced GHG emissions, increasing physical and economic factor efficiency. However, cost savings and profit earnings with these measures are relatively lower than reductions of energy consumed and GHG emissions which suggest an important role for policy incentives. Agro-environment measures in place for no tillage result in relevant positive profit impacts which are important for adapting this technology. Irrigated system increases profits as well as resource efficiency with lower primary energy consumption and GHG emissions per unit of production.

In the long run research and technological development of both options are worthwhile to promote competitiveness and sustainability of arable crop production systems of the Alentejo region of Portugal.

Figure 4. Differences of costs, profit, energy-use and greenhouse gas emissions (GHG) per ton between conventional and alternative technologies

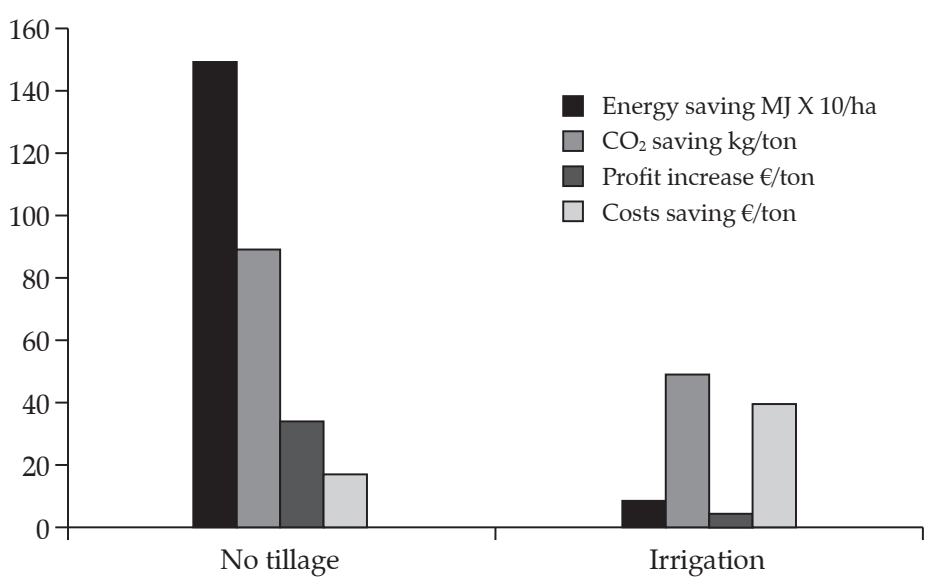

Source: AGREE spreadsheet results for arable crop system of Alentejo. 


\section{References}

ANSELMO, R. Planeamento de uma Exploração AgroPecuária localizada no Distrito de Évora sob Risco. Trabalho de fim de curso de Engenharia Zootécnica, Universidade de Évora, 1990.

AZEVEDO, A. L. and CARY, F. C. Sistemas de Exploração da Terra - Aspectos da Adaptação de Sistemas de Mobilização Mínima na Agricultura Mediterrânica, Separata do Volume XXXIII dos Anais do Instituto Superior de Agronomia, 1972.

BASCH, G. Alternativas para o Sistema Tradicional de Exploração da Terra no Alentejo tendo em consideração especial a Mobilização do Solo, Dissertação para a obtenção de equivalência ao grau de doutor em Ciências Agrárias, Universidade de Évora, 1991.

BASCH, G et al. Comparação de três Sistemas de Mobilização de solo em várias Culturas de Sequeiro, Resultados dos projectos de Investigação Agrária, Cooperação Luso-Alemã entre Universidades no domínio da Investigação Agrária Aplicada, Vila Real, 1989, p. 197-210.

CARVALHO, M. et al. Notas sobre a terminologia a utilizar em Sistemas de Mobilização do Solo. Revista de Ciências Agrárias, XIV, 2013, p. 3-8, 1991.

. and LOURENÇO, E. “Conservation agriculture - a Portuguese case study" Proceedings of the SWUP-MED Project Final International Conference "Sustainable water use for securing food production in the Mediterranean region under changing climate". Agadir, Morocco, 2013, p. 36-50.

CARVAlHO, M. Efeitos da Variabilidade das Produções Vegetais na Produção Pecuária - Aplicação em Explorações agro-pecuárias do Alentejo: Situações actual e Decorrente da Nova PAC, Dissertação de Doutoramento em Economia, especialidade Economia Agrícola, Universidade de Évora, 1994.

GOŁASZEWSKI, J. et al. State of the Art on Energy Efficiency in Agriculture. Report WP2 AGREE, 2012. Disponível em: <http://www.agree.aua.gr/Files/Agree_ State.pdf $>$.

INE, Instituto Nacional de Estatística, Recenseamento da Agricultura, 2009.

MARQUES, C. A. F. Portuguese Entrance into the European Community: Implications for Dryland Agriculture in the Alentejo Region, Ph.D. thesis, University of Purdue, USA, 1988.

MARQUES, F. and BASCH, G. Comparação da viabilidade económica de quatro sistemas de mobilização do solo. I
Congresso Nacional de Mobilização de Conservação do Solo, p. 283-298. Aposolo. Universidade de Évora, Évora, Portugal, 2002.

MARREIROS, C. A. Variabilidade das Produções Intermédias e a Produção Pecuária em Extensivo numa Exploração Agro-pecuária do Distrito de Évora. Trabalho de fim de curso de Engenharia Zootécnica, Universidade de Évora, 1992.

MARTINS, M. B. Avaliação Económica de Tecnologias Alternativas para a Mobilização do Solo numa Exploração Agrícola Característica da Zona dos Barros de Beja, tese de Mestrado em Economia Agrícola, Universidade de Évora, 1994.

- Avaliação Económica de Tecnologias Alternativas de mobilização do Solo em Situação de Risco, PhD Thesis, Universidade de Évora, Portugal, 2003.

. and MARQUES, C. Does risk influence the adoption of alternative soils tillage technologies? A compromise programming approach. New Medit, v. VI, n. 4, p. 4-13, 2007.

. and MARQUES, C. Methodological Aspects of a Mathematical Programming Model to Evaluate Soil Tillage Technologies in a Risky Environment. European Journal of Operational Research, v. 177/1, p. 556-571, 2006.

. and MARQUES, C. Tecnologias Alternativas de Mobilização do Solo: Avaliação Económica numa Exploração Característica da Zona dos Barros de Beja. Revista de Ciências Agrárias, v. XIX, n. 1, 1996.

. and MARQUES, C. Avaliação Económica de Tecnologias Alternativas de Mobilização do Solo. Publicações "Universidade de Évora", Série Ciências Económicas e Empresariais, no 3, Évora, 1995.

MEYER-AURICH, A. et al. Economic and Environmental Analysis of Energy Efficiency Measures in Agriculture, Report WP3 AGREE, 2013. Disponível em: <http://www.agree.aua.gr $>$.

NETO, M. Duas Perspectivas de análise do risco no rendimento dos agricultores do Alentejo - Variabilidade na Produção e variabilidade dos custos, Trabalho de fim de curso de Engenharia Agrícola, Universidade de Évora, 1992.

PORTARIA no 229-B/2008, 6 de Março. Valorização de modos de produção. Programa de Desenvolvimento Rural do Continente, PRODER.

ROSADO, M. Contributo para a Integração da Componente Ambiental na Avaliação Económica de Sistemas de Produção Agro-Pecuários, Dissertação de Doutoramento em Zootécnica, Universidade de Évora, 2009. 
